\title{
Comparative Study of Quality-Analysis of Three Different Bangladeshi Smoke-Dried Lean Fishes Using Salt and Turmeric Stored at Refrigeration Temperature $\left(4^{\circ} \mathrm{C}\right)$
}

\author{
Gulshan Ara Latifa ${ }^{1}$, Subhash Chandra Chakraborty ${ }^{2}$, Mohajira Begum $^{3}$, Farzana Binte Farid ${ }^{1}$, \\ Mosarrat Nabila Nahid,** \\ ${ }^{1}$ Department of Zoology, University of Dhaka, Dhaka 1000, Bangladesh \\ ${ }^{2}$ Department of Fisheries Technology, Bangladesh Agricultural University, Mymensingh, Bangladesh \\ ${ }^{3}$ Institute of Food Science and Technology, BCSIR, Dhaka 1205, Bangladesh \\ *Corresponding author: mnabilanahid@yohoo.com
}

Received October 30, 2014; Revised December 12, 2014; Accepted December 28, 2014

\begin{abstract}
This study evaluated shelf-life quality of salt and turmeric treated smoke-dried three different Bangladeshi lean fishes, Chapila (Gudusia chapra, Hamilton; 1822), Kaika (Xenentodon cancila; Hamilton; 1822) and Guchi Baim (Mastacembelus pancalus, Hamilton-Buchanan; 1822) by analyzed their biochemical (proximate and chemical)l composition and sensory evaluation during storage at refrigeration temperature $\left(4^{\circ} \mathrm{C}\right)$. There was a general decline in sensory characteristics i.e. color, texture, odor, general appearance and mean of acceptability of fish- product during storage. The differences in the biochemical comsition of the fresh and smoke-dried samples were statistically significant $(\mathrm{p}<0.05)$. Moisture $(\%)$ and TVB-N value $(\mathrm{mgN} / 100 \mathrm{gm})$ increased significantly whereas protein(\%), lipid (\%) and ash(\%) contant significantly decreased. The initial value of moisture, protein, lipid, ash and TVB-N of freshly smoke-dried Chapila, Kaika and Guchi-Baim fish was 6.21\%, 45.93\%, 30.81\%, 18.95\% and $4.65 \mathrm{mgN} / 100 \mathrm{gm}, 8.24 \%, 63.04 \%, 6.71 \%, 22.52 \%$ and $8.84 \mathrm{mgN} / 100 \mathrm{gm}$ and $6.97 \%, 59.22 \%, 11.67 \%, 22.54 \%$ and $6.62 \mathrm{mgN} / 100 \mathrm{gm}$ respectively. Among these three fish species smoke-dried kaika fish product became spoiled at the end of 9month whereas smoke-dried Chapila and Guchi Baim fish product still remain in good condition. The shelf-life of smoke-dried Chapila and Guchi Baim fish product was 18 month and 27 month. Because of using salt and turmeric as natural preservative, no yeast or mould was detected in this three smoke-dried fish samples. Therefore, it can be inferred that salt and turmeric treated smoke-dried Guchi Baim fish product has longer shelf life than another two fish products.
\end{abstract}

Keywords: smoke-drying, biochemical-composition, sensory-evaluation, chapila, Kaika, Guchi-Baim, saltturmeric

Cite This Article: Gulshan Ara Latifa, Subhash Chandra Chakraborty, Mohajira Begum, Farzana Binte Farid, and Mosarrat Nabila Nahid, "Comparative Study of Quality-Analysis of Three Different Bangladeshi SmokeDried Lean Fishes Using Salt and Turmeric Stored at Refrigeration Temperature $\left(4^{\circ} \mathrm{C}\right)$." American Journal of Food Science and Technology, vol. 2, no. 6 (2014): 209-215. doi: 10.12691/ajfst-2-6-7.

\section{Introduction}

Fish is one of the most diverse groups of animals known to man with more than 20,500 species in existence. The World fish production from capture fisheries and aquaculture has reached 121 tones [1]. Fish allows for protein improved nutrition in that it has a high biological value in term of high protein retention in the body, low cholesterol level and presence of essential amino acids [2]. A decline in fish availability will have a detrimental effect on the nutritional status of the citizenry particularly in places where fish contributes significantly to the protein intake of the people. In Bangladesh, fish provides 63\% of national animal protein consumption [3]. At present the
Fisheries Sector in Bangladesh represents as one of the most productive and dynamic sectors in the country. This sector plays a significant role in employment, nutrition, and foreign exchange earnings in the economy of Bangladesh. Bangladesh earning huge amount of foregoing exchange through the export of fish and fish products to U.K, Hong Kong, Singapore, USA, Saudi Arabia and others. The demand for fish in International market had increased substantially in recent years. All- out efforts are being made for increased production of fish, so that more fish are available for export.

Fishes are rapidly perishable food items and lean fishes being small in size have a tendency to become spoiled more quickly than larger fishes. Once upon a time small sized fishes were the only source of animal protein for the 
poor and neglected class peoples in Bangladesh. But such a scenario has started to change from the mid of twentieth century and at present, the small indigenous fishes have turned into a delicious dish for all classes peoples. Besides their demand is increasing rapidly among the middle to upper-middle class people mainly to meet up the daily requirement of animal protein for the family. Whereas, an indiscriminate and unscientific harvest as well as loss of natural habitat through several government taken schemes and natural disasters, the population of this small size fishes are decreasing drastically from the recent years.

As fish is highly perishable material, so whatever may be the amount of harvest, it has no value until it reaches the consumer as food. Proper pre-treatment or processing of premium quality fresh fish can minimize the post harvest loss and thus reduced the amount of fish spoilage.

Spoilage proceeds as a series of complex enzymatic, bacterial and chemical changes that start in some few hours after fish being caught depending on the species and the prevailing ambient temperature. This may render it unacceptable and unfit for human consumption. Plenty of fish is available during the fishing season when the fishermen for want of speedy transport facilities can not send to the market for sale. Thus the fishermen either have to sell their catch at a cheaper rate or they have to let their catch go waste due to lack of proper processing and strong facilities. If the bulk could be processed or preserved for short term or long term period and stored successfully the requirement of the off season would have been met up to a significant extent. Proper preservation starts the moment it is harvested until reaches the consumer's table [4]. Efforts should therefore, be geared towards increased fish production through improved resource management matched with effective post-harvest handling, preservation and processing to prevent spoilage. Consequently, research is needed to improve their shelf life and nutritional values in traditional preservation techniques, so in the peak harvesting periods, these fish could preserve properly to serve in lean periods as a cheap and immediate source of animal protein to all classes peoples.

To prolong the shelf life of fish, some preservation methods used in the tropics include chilling, freezing, drying, salting and smoking.. Fish smoking and its effect have been of interest to several researchers [5-11]. Many of these authors have reported that smoking of fish accelerates drying (that is, lowers moisture content or water activity) and prevents microbial activities on the fish. Among the several methods of long term preservation of fish, smoking is perhaps the simplest method as it does not require sophisticated equipment or highly skilled workers [8]. On the other hand, smoke curing method is a method which is not affected by climatic condition as well as the smoke cured production has a special taste and odor. It also has world wide acceptability as processed fish food. In Bangladesh, considerable work has been done on smoked large fish species such as smoked thai pangus, smoked Ilish, smoked Tilapia but no serious attempt has yet been made to preserve smoke-dried lean fishes Due to high palatable, taste and rich in nutrients three commercially nutritionally important variety of Bangladeshi freshwater lean fish species such as Chapila, Kaika and Baim have been selected for the present research work. These fishes are rich in protein and fat content as well as different vitamins and minerals.
In Bangladesh smoked fish is recent addition to the fishery products. Fish is normally salted before smoking. Different salting methods are being practiced by the smoked fish industry in different parts of the world $[12,13]$. But in this research work salt \& turmeric used before smoke-drying which are easily available and cheaper cost wise.

Salt has been used as a preservative since ancient times, to protect food against bacteria, mold, and spoiling. Basically, salt works by drying food. Salt absorbs water from foods, making the environment too dry to support harmful mold or bacteria. Table salt or sodium chloride is a common preservative because it is non-toxic, inexpensive, and tastes good. Whereas turmeric is one of the oldest known anti-bacterial ingredients used by the ancient civilizations. Turmeric (Curcuma longa) has long been used as a coloring and flavoring agent for foods. Curcuminoids are the main component of turmeric and have a range of pharmacological activities [14]. In Bangladesh, turmeric is easy available and is considered as one of the important ingredient for cooking any kind of dish. Even in some parts of Bangladesh, rural people usually use turmeric for short time preservation of small sized fishes. But, there is very few scientific information about the use of turmeric in fish preservation.

Due to the consumer awareness of chemical preservatives, extensive studies are been made on natural preservatives for preservation of meat and fish products. The objectives for this study was to extend the shelf life of fish treated with salt and turmeric solution/ extracts which would not alter the taste and flavor of the food product or add a new undesirable taste. Salt and turmeric were selected because they are often used while cooking fish and easily available in the local market.

Thus, this research is aimed at studying the effectiveness of fresh salt and turmeric on extending the shelf-life by analysis biochemical composition (proximate and chemical composition) and sensory evaluation of smoke-dried Chapila, Kaika and Guchi Baim fish during storage at refrigeration temperature $\left(4^{\circ} \mathrm{C}\right)$

\section{Materials and Methods}

\subsection{Sample Collection}

Three freshwater fish species; Chapila (Gudusia chapra), Kaika (Xenentodon cancila) and Guchi Baim (Mastacembelus pancalus) was collected from the Meghna River early in the morning. Fresh mature fish samples were transported to laboratory in sterile polythene to avoid any type of microbial contamination. This study was conducted between January 2012 to July 2014 at the Fish Technology Section of the Institute of Food Science and Technology (IFST) of Bangladesh Council of Scientific and Industrial Research (BCSIR), Dhanmondi, Dhaka.

\subsection{Preparation of Sample}

At first, the collected Chapila fish was discaled while Kaika and Guchi Baim fish was beheaded. Then three fish samples were gutted and washed properly with clean water. The dressed fish samples were then weighed and prepared for further processing. 


\subsection{Preparation of Samples for Processing}

The dressed fish samples were then dip in freshly prepared $30 \%$ salt and $10 \%$ turmeric solution for 15 minutes followed by draining.

\subsection{Fish Smoke-drying}

The fishes were smoked in improved traditional type of smoking kiln [15]. The fish smoking kiln was operated by first loading tamarind wood chips and rice-husk into the heat chamber, preheating for some minutes and then loading the fish-samples onto removable wire mesh trays in its central chamber for the smoke-drying process. The desired temperature $\left(75-80^{\circ} \mathrm{C}\right)$ was maintained manually. Smoking was done approximately for 4 hours. During the smoking fish samples were turned upside down in the middle period, to make the sample smooth and steady in texture and appearance. The smoke-dried fishes showed characteristic attractive golden brown color and acceptable texture with smoky flavor, which was followed by cooling for 20-30 minutes at ambient temperature to make fish muscle compressed and facilitate to prevent breaking of smoked products. The cooled smoked fish samples were then packed and sealed in vacuum condition with marking taken in three different polythene bags (transparent). Three groups of smoke-dried fish product were then kept for storage at refrigerator temperature for further analysis of sensory and biochemical compositions.

During the storage period the three types of smokedried fish samples were checked on three month interval basis.

\subsection{Estimation of Sensory Score Value}

The quality assessment as well as sensory evaluation (score) was carried out every three months intervals for samples stored at refrigeration temperature $\left(4^{\circ} \mathrm{C}\right)$ using trained panel of four judges until it was an acceptable condition [16].

The questionnaires were prepared using 9- point hedonic score described by Larmond to evaluate changes in color, flavor, texture and mean of general acceptability until it was an acceptable condition.

Parameters on the questionnaires were as follows: Like extremely $=9$; Like very much $=8$; Like moderately $=7$; Like slightly $=6$; Neither like nor dislike $=5$; Dislike slightly $=4$; Dislike moderately $=3$; Dislike very much = 2 ; and Dislike extremely $=1$ [17].

\subsection{Estimation of Biochemical Composition}

Using conventional method of AOAC (Association of Official Analytical Chemicals), the proximate composition of fish was determined [18].

\subsubsection{Estimation of Moisture}

About 5 gram of previously prepared fairly minced samples were taken into each known weight basin and weighed in a digital balance (Toledo, Switzerland). The samples were allowed to dry into the oven (Memmet 854 Schwabach) at $105^{\circ} \mathrm{C}$ for 24 hours in order to remove the moisture until constant weight. After that, the basins are taken out of the oven, cooled in a desiccators and were weighed in a digital balance.
Calculation

$$
\% \text { of Moisture }=\frac{\text { Weight Loss }}{\text { Original Weight of Sample Taken }} \times 100
$$

\subsubsection{Estimation of Protein}

The protein content was estimated using conventional micro-kjeldahl method [19].

Calculation

$$
\begin{aligned}
& \% \text { of } \mathrm{N}_{2}(* \mathrm{~A}) \times \text { strength of acid } \times 0.002 \times \frac{100}{5} \times 100 \\
& \text { weight of sample taken } \\
& \text { *A = titration reading - blank reading }
\end{aligned}
$$

For most routine purposes the percent of protein in the sample is then calculated by multiplying the\% of $\mathrm{N}_{2}$ with an empirical factor of 6.25 for fish.

$$
\% \text { of protein }=\% \text { of total } \mathrm{N}_{2} \times 6.25
$$

\subsubsection{Estimation of Fat}

About $5 \mathrm{~g}$ of the homogenous sample was taken into conical flasks and $10 \mathrm{ml}$ of folch reagent (Chloroform: Methanol = 2:1) was added into the sample and homogenized properly and kept in air-tight condition for 24 hours. Fat contents of the fish muscle react with that solvent and remains in the solution. After 24 hours the solution of the flask was filtered in another weighed conical flask through a filter paper. Then these flasks were given in a hot water bath to dry up and removed the solvent. After that the flasks were kept into an oven for an hour to get the actual fat content. Then the flasks were weighed in an electronic balance to get the amount of fat content.

Calculation

$$
\% \text { of Fat }=\frac{\text { Weight of the residue }}{\text { Weight of sample taken }} \times 100
$$

\subsubsection{Estimation of ash}

About 4-5 g fish sample was weighed into a preweighed crucible. The crucible with the contents was heated first over a long flame till all the material was completely churned. Then it was transferred in the Muffle Furnace held at dark red at a rate of $600^{\circ} \mathrm{C}$ for 5 hours until the residue become white. The crucible were cooled in desiccators and weighed. Finally the\% of ash content was calculated.

Calculation

$$
\% \text { of ash }=\frac{\text { Weight of fish }}{\text { Weight of sample taken }} \times 100
$$

\subsubsection{Estimation of TVB-N (Total Volatile Base Nitrogen)}

TVB-N value was determined by using Conway modified micro-diffusion technique [20]. Samples that were in the different levels of acceptability from highly acceptable condition to unacceptable condition had been selected for TVB-N analysis. $25 \mathrm{ml}$ of $10 \%$ Trichloro Acetic Acid (TCA) was added to 2 gm of ground fish sample and kept overnight and then filtrated with known volume. $2 \%$ boric acid, TCA, $\mathrm{K}_{2} \mathrm{CO}_{3}$ and the solutions 
made from the fish samples were taken into the Conway dishes.

After the addition of Potassium Carbonate $\left(\mathrm{K}_{2} \mathrm{CO}_{3}\right)$, each dish was covered by a piece of glass that was stacked with glue (Paraffin soft white) initially. Then it was kept for 24 hours. The samples and Potassium Carbonate $\left(\mathrm{K}_{2} \mathrm{CO}_{3}\right)$ reacts to form $\mathrm{NH}_{3}$ which was absorbed by the boric acid and then the solution of each Conway dish had been titrated by $\mathrm{N} / 70 \mathrm{H}_{2} \mathrm{SO}_{4}$ with the help of a microburette.

Finally TVB-N was calculated.

Calculation

TVB-N $=(* A) \times$ Strength of acid $\times 0.2$

$$
\begin{aligned}
& \times \frac{\text { Volume of extract }}{\text { Volume of extract taken }} \times \frac{100}{\text { Weight of sample taken }} \\
& (* \mathrm{~A}=\text { titration reading }- \text { blank reading })
\end{aligned}
$$

To calculate significance at $\mathrm{p}<0.05$ level all data was analyzed with the help of SPSS for windows, version 20 statistical software.

\section{Results and Discussion}

In Bangladesh among the freshwater small fish species, Chapila, Kaika and Guchi Baim fishes are very delicious, high market prise, nutritious and popular to the consumers. So these fishes are very important due to commercial purpose.

Moisture, protein, fat, ash and TVB-N of fresh Chapila fish was $76.41 \%, 10.53 \%, 11.62 \%, 1.50 \%$ and $2.40 \mathrm{mgN} /$ 100 g, fresh Kaika fish was $77.67 \%, 14.27 \%$, 4.66\%, 2.94\% and 4.92mgN/100gm and Guchi Baim fish was 77.21\%, 15.17\%, 6.13\%, $1.72 \%$ and $3.16 \mathrm{mgN} / 100 \mathrm{~g}$ respectively (Figure 1). Fresh sample presented low protein content [21].

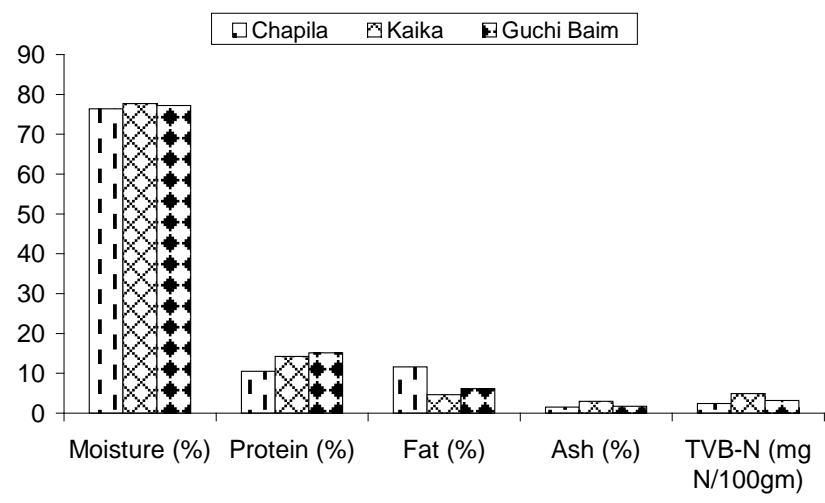

Figure 1. Changes in biochemical composition of fresh chapila, Kaika and Guchi Baim fish

\subsection{Sensory Score Value}

Sensory methods are considered to be the most useful and dependable criteria for assessing the degree of freshness for quality determination. Human being is capable to detect defects from visual signs of deterioration such as loss of freshness and changes during storage period. Sensory quality assessment is an easy, quick and efficient method of getting idea about the quality of the product. This method is based on the response or tendency of sense organ for accepting the food products.
Sensory characters (color, texture, flavor, general appearance) of these three types of salt and turmeric treated smoke-dried fish samples showed that apart from the preservative effect of turmeric, it also acted as a flavoring substances. The aroma from all these three salt and turmeric treated smoke-dried fish samples were characteristically desirable.

The shelf-life of these three types of smoke-dried fish product was found to be related to the temperature and the length of storage. At the beginning of storage all the sensory parameters of these three samples were rated as good based on the grading scale. The highest mean of general acceptability score was found 8.86 in case of S+T Chapila, 8.83 in case of S+T Kaika and 8.87 in case of $\mathrm{S}+\mathrm{T}$ Guchi Baim smoke-dried fish products. The mean of general acceptability score decreased as storage-duration increased. In this study the shelf-life of salt and turmeric treated smoke-dried Chapila, Kaika and Guchi Baim fish was 18, 9 and 27 month. The mean of general acceptability score of the end product of smoke-dried Chapila, Kaika and Guchi Baim was 3.71 (18 month), 4.80 (9 month) and 4.24 (27 month) respectively. At the end of 12 month smoke-dried Kaika fish product became spoiled whereas smoke-dried chapila and Guchi Baim fish products were still remain in good condition (Figure 1).

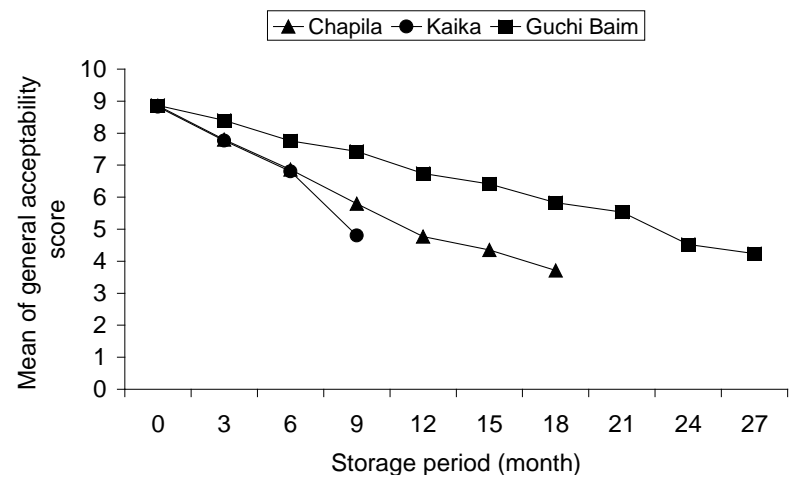

Figure 2. Changes in mean of general acceptability score of salt and turmeric $(\mathrm{S}+\mathrm{T})$ treated smoke-dried Chapila, Kaika and Guchi-Baim fish during storage at refrigerator temperature $\left(4^{\circ} \mathrm{C}\right)$

This agrees with the results of research into storage of smoke dried fish and crustaceans (Oyster and shrimps which revealed quality loss during storage both at ambient temperature and chilling [22,23,24].

\subsection{Biochemical Analysis}

During smoke-drying, the percentage of moisture content decreased and protein, lipid and ash content increased significantly $(\mathrm{p}<0.05)$ due to water loss. This observation is in agreement with the findings of Atlantic mackerel and European eel, pike perch and rainbow trout [25,26].

\subsubsection{Moisture (\%) Content}

The moisture content can be used as a pointer to the rate at which deterioration occurred in fish samples resulting in the early decomposition. During storage at refrigeration temperature, percent of moisture were found to vary from $6.21 \%$ (o day) to $10.04 \%$ (18 month) for saltturmeric treated smoke-dried Chapila, $8.28 \%$ (o day) to $10.14 \%$ (9 month) for salt-turmeric treated smoke-dried Kaika and $6.97 \%$ (o day) to $8.54 \%$ (27 month) for salt- 
turmeric treated smoke-dried Guchi Baim fish respectively (Figure 3, Figure 4, Figure 5). There was a gradual increase in the moisture content of this three types of saltturmeric treated smoke-dried fish samples with increasing storage period. The gutted smoke dried fish samples of African cat fish (Clarias nigrodigitus) had moisture content as 6.27 to $10.92 \%$ which is similar with present study [27]. Moisture content of $12 \%$ is the level beyond which fish products begin to grow moulds after few days [28]. In this study the final moisture of salt-turmeric treated smoke-dried fish samples was less than $12 \%$.

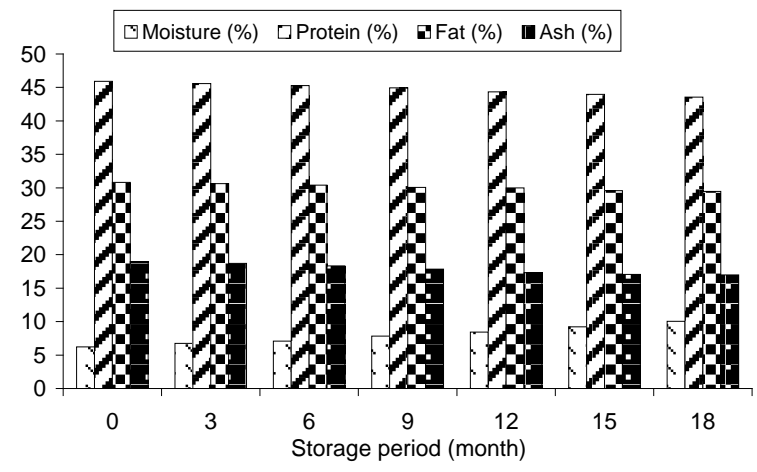

Figure 3. Changes in Proximate Composition of salt and turmeric $(\mathrm{S}+\mathrm{T})$ treated smoke-dried Chapila fish during Storage at refrigerator temperature $\left(4^{\circ} \mathrm{C}\right)$

\subsubsection{Protein (\%) Content}

Significant increased in protein levels $(\mathrm{p}<0.05)$ in three types of smoke-dried fishes when compared with the fresh fish, suggested that protein nitrogen was not lost during smoke-drying $[29,30]$.

Protein decomposes with passing time [31]. Protein (\%) were found to vary from $45.93 \%$ (o day) to $43.55 \%$ (18 month) for salt-turmeric treated smoke-dried Chapila, $63.04 \%$ (o day) to $62.32 \%$ (9 month) for salt-turmeric treated smoke-dried Kaika and 59.22\% (o day) to 58.47\% (27 month) for salt-turmeric treated smoke-dried Guchi Baim respectively (Figure 3, Figure 4, Figure 5). In storage condition, the protein content decreased significantly with the time due to water soluble protein diffused out to the surrounding for exosmosis [32]. This could be due to gradual degradation of initial crude protein to more volatile products such as total volatile bases, hydrogen sulphide and ammonia [33]. Similar drop in protein concentration was reported for Heterobranchus longifilis [34].

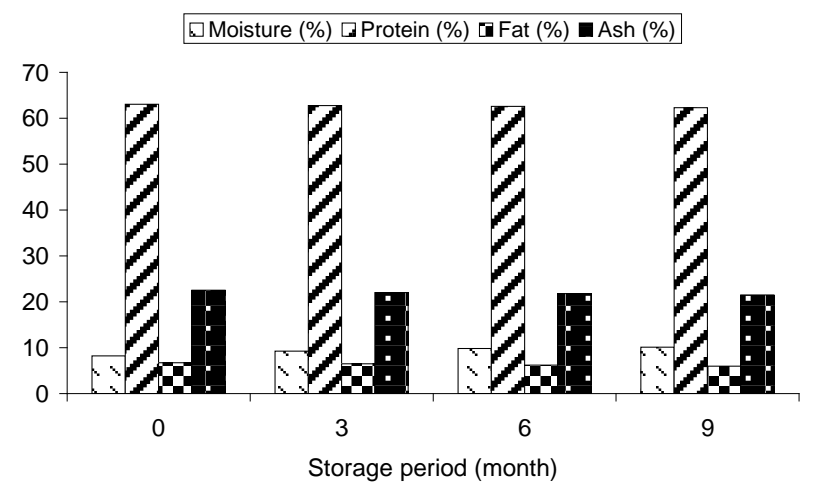

Figure 4. Changes in Proximate Composition of salt and turmeric $(\mathrm{S}+\mathrm{T})$ treated smoke-dried Kaika fish during Storage at refrigerator temperature $\left(4^{\circ} \mathrm{C}\right)$

\subsubsection{Fat (\%) Content}

Fat (\%) were found to vary from $30.81 \%$ (o day) to 29.46\% (18 month) for salt-turmeric treated smoke-dried Chapila, 6.71\% (o day) to 5.96\% (9 month) for saltturmeric treated smoke-dried and $11.67 \%$ (o day) to $10.97 \%$ (27 month) for salt-turmeric treated smoke-dried Guchi Baim respectively (Figure 3, Figure 4, Figure 5). Usually moisture and fat contents in fish flesh are inversely related and there sum is approximately $80 \%$ [35]. This inverse relationship was also well defined in this experiment.

\subsubsection{Ash (\%) Content}

Ash (\%) was found to vary from $18.95 \%$ (o day) to $16.99 \%$ (18 month) for salt-turmeric treated smoke-dried Chapila, $22.52 \%$ (o day) to $21.47 \%$ (9 month) for saltturmeric treated smoke-dried and $22.54 \%$ (o day) to $21.71 \%$ (27 month) for salt-turmeric treated smoke-dried Guchi Baim respectively (Figure 3, Figure 4, Figure 5). The ash content changes with the time of storage due to absorbance of moisture and loss of protein [32]. Smaller sized fish species has higher ash content due to the higher bone of flesh ratio [36].

During storage at refrigeration temperature, after 9 month it was found that the salt-turmeric treated smokedried Kaika fish product was spoiled while the saltturmeric treated smoke-dried Chapila and Guchi Baim fish were found to be in their normal characteristics up to 18 and 27 months. Because of antifungal effect of turmeric, there is no fungal attack shown on salt-turmeric treated smoke-dried Chapila, Kaika and Guchi Baim fish product.

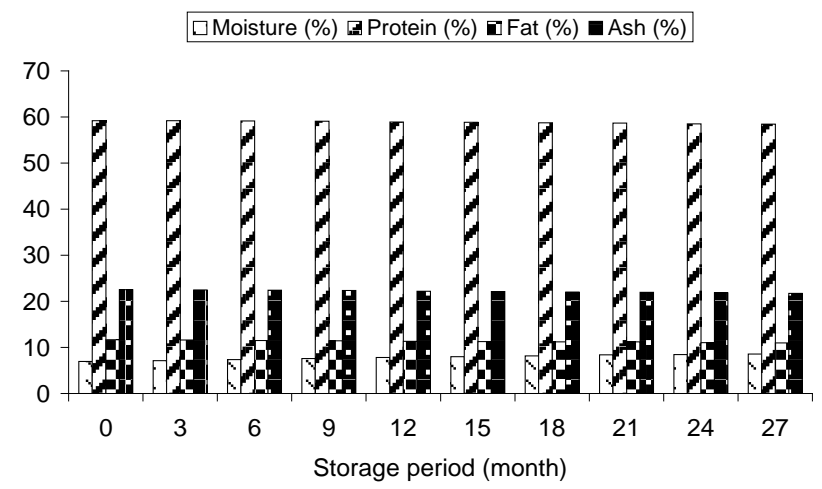

Figure 5. Changes in Proximate Composition of salt and turmeric $(\mathrm{S}+\mathrm{T})$ treated smoke-dried Guchi-Baim fish during storage at refrigerator temperature $\left(4^{\circ} \mathrm{C}\right)$

Significant statistical differences were found between the initial product and end product $(\mathrm{P}<0.05)$ after storage period.

\subsubsection{TVB-N value}

It was observed that spoilage of fish flesh resulted from the action of enzymes and bacteria; this can be slowed down through the application of salt and removal of moisture to increase the shelf life of fish.

Total Volatile base Nitrogen (TVB-N) is widely used as an indicator of the degree of lipid oxidation [37]. It helps to measure the level of fish spoilage and to explore the shelf life of fish. During storage period total volatile base nitrogen value (TVB-N) increased. In salt-turmeric treated smoke-dried Chapila fish product, the TVB-N values 
ranges from 4.65 (0 day) to $20.77 \mathrm{mgN} / 100 \mathrm{~g}$ (18 month) whereas ranges of TVB-N value was 8.84 (0 day) to 20.04 (9 month) mgN/100g in salt-turmeric treated smoke-dried Kaika and 6.62 (0 day) to 19.07 (27 month) mgN/100g in salt-turmeric treated smoke-dried Guchi Baim fish product respectively (Figure 6).

Pearson recommended that the limit of acceptability of fish is $20-30 \mathrm{mg} N$ per $100 \mathrm{~g}$ [38]. While Kirk and Sawyer suggested a value of $30-40 \mathrm{mg} N / 100 \mathrm{~g}$ as the upper limit [39]. Increase in final values of TVB-N in this study is similar with other researchers [34,40]. During hot smoking fish are exposed to heat and atmospheric oxygen. These factors can accelerate the oxidation of the fish lipids resulting in an increased in TBA [41].

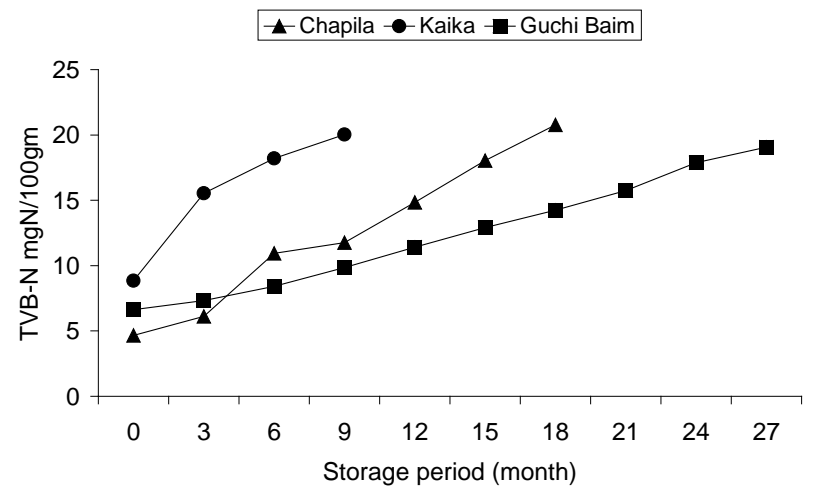

Figure 6. Changes in TVB-N value of salt and turmeric $(S+T)$ treated smoke-dried Chapila, Kaika and Guchi-Baim fish during storage at refrigerator temperature $\left(4^{\circ} \mathrm{C}\right)$

\section{Conclusion}

The results of biochemical analysis and sensory evaluation carried out proves that the overall shelf-life quality of Guchi Baim fish product is best among the three salt and turmeric treated smoke-dried fish products. However, subsequent uses of salt and turmeric solution is required to keep these fish products longer from deterioration. The present studies has added information that the percentage of protein of salt and turmeric treated smoke-dried Kaika and Guchi Baim are quite satisfactory whereas salt and turmeric treated smoke-dried Chapila fish product contain a high percentage of lipid. From this research, it can be concluded that smoke-dried lean fish products can provide satisfactory nutrition to the nation.

\section{Acknowledgements}

The author acknowledges the scientist and technicians of BCSIR, Dhaka, Bangladesh for their technical help.

\section{References}

[1] FAO. World catch and Trade of Fisheries Productions in 1984. Info Fish Marketing Digest. No. 25. 1985.

[2] Emikpe B.O., Adebisi T. and Adedeji O.B. Bacteria load on the skin and stomach of Clariasm gariepinus and Oreochromis niloticus from Ibadan, South West Nigeria: Public health implications. J. Microbiol. Biotech. Res., 1 (1): 52-59. 2011.

[3] Hasan, M. ed. "Overview of Fish Industry in Bangladesh”. Paper presented in International Conference on Aquaculture Production and Marketing of Shrimp -Finfish \& Bangladesh Seafood Expo, pp 19-21. 2004.

[4] Oluborode GB, Omorinkoba WS, Bwala RL. Development and Construction of an Electric Furnace and Control System for fish drying. Afr. J. Eng. Res.Dev. (Devon Science Publication). 3 (2): 123-128. 2010.

[5] Efiuwevwere BJO, Iweanoge HA. Microbioloical and physicchemical quality of various tissue types of fresh potassium sulphate treated and untreated smoked (Mugilcephalus). World J. Microbiol. Biotechnol. 7 (5): 562-566. 1991.

[6] Aminullah-Bhugan AKM, Ratnayake WMN, Ackman RG. Effect of smoking on proximate composition of Atlantic Mackerel. J. Food Sci. 51 (2): 327-329. 2006.

[7] Ahmed A, Dodo A, Bouba A, Clement S, Dzudie T. Influence of traditional drying and smoke-drying on the quality of three fish species (Tilapia nilotica, Silurusglanis and Arius parkii) from Lagdo Lake, Cameroon. J. Anim. Vet. Advan. 10 (3): 301-306. 2011.

[8] Olayemi FF, Adedayo MR, Bamishaiye EI, Awagu EF. Proximate composition of catfish (Clarias gariepinus) smoked in Nigerian stored products research institute (NSPRI) developed kiln. Int. J. Fisheries Acquacult. 3 (5): 96-98. 2011.

[9] Aliya G, Humaid K, Nasser A, Sami G, Aziz K, Nashwa M, Ponnerassery SS. Effect of the freshness of starting material on the final product quality of dried salted shark. Advan. J. Food Sci. Technol. 4 (2): 60-63. 2012.

[10] Omodara MA, Olaniyan AM. Effects of pre-treatments and drying temperatures on drying rate and quality of African catfish (Clarias gariepinus). J. Biol. Agric. Healthcare 2 (4): 1-11. 2012.

[11] Okafor N, Nzeako BC. Microbial floral of fresh and smoked fish from Nigerian freshwater. Food microbial. 2: 71-75. 1985.

[12] Espe, M. Nortvedt, R. Lie, O. and Hafsteinsson, H. Atlantic salmon (Salmo salar), as raw material for smoking industry. 1: effect of different salting methods on the oxidation of lipids. Food Chem. 75 (4): 411-416. 2001.

[13] Jittinandana, S. Kenney, P.B. Slider, S.D. and Kser, R.A. 2002. Effect of brining concentration and brining time on quality of smoked rainbow trout fillets. J. Food Sci. 67 (6): 2095-2059. 2002.

[14] Santosh P, Hye JK, Jeong EK, Jae GJ. Separation of an effective fraction from turmeric against Streptococcus mutans biofilms by the comparison of curcuminoid content and anti-acidogenic activity. Food Chem. 126: 1565-1570. 2011

[15] Sarkar. A study on the shelf-life of smoked thai pangus (Pangasius hypophthalmus). M.Sc. Thesis submitted to Bangladesh Agricultural University, Mymensingh, pp. 71. 2005.

[16] Debnath, S.K.. A study of the improved technique for the production of smoked Thai Pangas (Pangasius hypopthalmus). M.Sc. thesis. Bangladesh Agricultural University, Mymensingh. 32pp. 2009.

[17] Larmond, E. Laboratory methods for sensory evaluation of food. Research Branch, Canada Dept. of Agriculture Publication 1637. 1977.

[18] AOAC,. Official method of analysis. Association of Official Agricultural Chemists W. Horwitz (Editor) $12^{\text {th }}$ ED. Washington. 1990.

[19] Pearson, D. Pearson's composition and analysis of foods. University of Reading. 1999.

[20] Conway, E. J. and Byrne, A. Micro-diffusion analysis of TVN. Biochem. J. 27, 419-429. 1933.

[21] Eyo, A.A. Shelf-life of Moon fish (Citharinus citharus) and Tumk Fish (Mormyrus rume) During storage at ambient temperature and on Ice. FAO Fisheries Report No. 574: 35-37. 1998.

[22] Daramola, J.A. Fasakin, E.O. Adeparusi, E.O. Changes in physicochemical and sensory characteristics of smoke-dried fish species stored at ambient temperature. African Journal of Food and Agriculture, Nutrition and Development. 7 (6): 169-183. 2007

[23] Llobreda, A.T. Bukalacao, M.L. Sunaz, N. Effects of Storage on the Microbial Quality of Slipper oyster (Cassostera iredalei). In: Maclean JL, Izon LBD, Hosilus LV (Eds). The First Asian Fisheries Forum, Manilla, Philippines. 1986.

[24] Reilly, A.E. Dela-cruz, D. Post- harvest spoilage of shrimp (Penaeus monodon). In: Maclean JL, Dixon LB, Hossillus LV (Eds). The first Asian Fish Forum. Manilla, Phillipines. 1986.

[25] Bhuiyan, A.K.M. Ratnayake, W.M.N. Acman, R.G. Effect of smoking on the proximate composition of Atlantic mackerel (Scomber scombrus). J. Food Sci. 51: 327-329. 1986. 
[26] Unlusayin, M. Kaleli, S. Gulyavuz, H.. The determination of flesh productivity and protein components of some fish species after hot smoking. J. Sci. Food Agric. 81: 661-664. 2001.

[27] Faturoti, E.O. Biological utilization of sun-dried and smoked African Cat fish (Chrysichthys nigrodigitus). Nutritative Reports International, Rwp. of Wildlife and Fisheries Management, Univ. of Ibadan, Nigeria. 30 (6), 1395-1400. 1985.

[28] FAO/APHCA. The use of palm-Kernel cake as Animal feed. FAO/APHCA Publication No. 8. 1989.

[29] Puwastien, P. Judprasong, K. Kettwan, E. Vasanachitt, K. Nakngamanong, Y. Bhattacharjee, L. Proximate composition of raw and cooked Thai Freshwater and Marine Fish. J. Food Composition Anal., 12: 9-16. 1999.

[30] Tao, W. Linchun, M.. Influence of hot Air Drying and Microwave Drying on Nutritional and odorous Properties of Grass Carp (Ctenopharyngodon idellus) Fillets. Food Chem., 110 (3): 647-653. 2008.

[31] Ghezala, S.. "New Packaging Technology for Seafood Preservation Shelf Life Extension and Pathogen Control”. In: Fisheries Processing Biotechnological Applications. A.M. Martin (ed.). Chapman Hall: London, UK. 83-110. 1994.

[32] Hassan, M.N. Rahman, M. Hossain, M.M. Nowsad, A.A.K.M. and Hossain, M.B. Post-Harvest Loss and Shelf Life of Traditionally Smoked Shrimp Products Produced in Bangladesh. World J. of Fish and Marine Sci. 5 (1): 14-19. 2013.

[33] Eyo, A. A.. Fish processing technology in the tropics, University of Ilorin Press. 403pp 2001.
[34] Abolagba, O.J. and Osifo, S.J.. "The Effect of Smoking on the Chemical Composition and Keeping Qualities of Catfish (Heterobranchus bidorsalis) using Two Energy Sources”. Journal of Agriculture, Forestry and Fisheries (JAFF). 5 (1), 27-30. 2008.

[35] FAO. World production of fish, crustaceans and mollusks by major fishing areas. Fisheries Information Data and Statistics unit (FIDI), Fisheries Department, FAO Rome., 33 pp. 1999.

[36] Daramola, J.A. Fasakin, E.A. Adeparusi, E.O.. Changes in physicochemical and sensory characteristics of smoke-dried fish species stored at ambient temperature. 10 pp. 2007.

[37] Daramola, J.A. Kester, C.T. and Allo, O.O. Biochemical evaluation of hot-smoked African catfish (C. gariepinus) sampled from Sango and Ota market in Ogun State. 382 pp. 2013.

[38] Pearson, D. The Chemical Analysis of Foods. Churchill Livingstone, Edinburgh, London and New York. 1982.

[39] Kirk, R.S. and Sawyer, R.. Nitrogen Determination. Pearson's Composition and Analysis of Foods. Longman Scientific Publisher: London, UK. 29-36. 1991.

[40] Trinidad, L. M. and Estrada, M.H. "Effect of Raw Material Freshness on the Quality of Smoked Tilapia (Oreochromis niloticus)”. In: J.L. Maclean, L.B. Dixon, and L.V. Hosilus (eds.). The First Asian Fisheries Forum. Manilla, Philippines. 471-472. 1986.

[41] Bilgin, F. Unlusayin, M. and Gunlu, A. "The Determination of the Shelf Life and Some Nutritional Components of Gilthead Seabream (Sparus aurata L., 1758) after Cold and Hot Smoking". Turk. J. Vet. Anim. Sci. 32 (1): 49-56. 2008. 